\title{
Headloading in Africa: Preliminary Findings on the Locomotor Effects of Occupational Headload Carriage
}

\author{
J. CHARTERIS, P. A. SCOTT AND J. C. WALL
}

\section{SUMMARY}

Headload walking is widespread in Africa, potentially medically harmful, but poorly understood. The present pilot study reveals what portions of the locomotor pattern deserve detailed further study. Basically under the headload condition, shorter, quicker more mincing steps are taken, raising the energycost of locomotion. Shock-absorption mechanisms are impaired. Propulsive mechanisms are altered.

\section{INTRODUCTION}

Head-loading is a ubiquitous African phenomenon particularly among women, as a means of heavy-load transporting. Its roots, however, are to be found in economy of effort, not cultural or ethnic tradition, for headloading is commonly practised in Tibet, Nepal, the high Andes, Papua and across Africa. As Datta and Ramanathan' have shown, it is one of the least energy expensive means of load carriage, ahead of backpacking, back- and head-sling (Sherpa) loading, the shoulder yoke method, and bi-manual load carrying. Clearly millenia of arduous load bearing has resulted in this near-universal adoption of the least fatiguing feasible method of carrying awkward loads.

That head-load carrying is physiologically efficient is established; what has not been adequately considered are the long-term orthopaedic effects of the practice. Eke-Okoro and Sandlund ${ }^{2}$ studied the walking patterns of people in the street and found that those carrying shopping bags or suitcases exhibited shorter stride

J. CHARTERIS, B.A., M.Sc.

Professor, and Head of the Department of Human Movement Studies, Rhodes University, Grahamstown

P. A. SCOTT, B.A., M.A., Lecturer, Department of Human Movement Studies, Rhodes University, Grahamstown

J. C. WALL, Ph.D., Associale Professor, School of Physiotherapy, Dalhousie University, Halifax, Canada

\section{OPSOMMING}

Van stap met 'n las op die kop, wat wyd verspreid in Afrika voorkom en potensieel medies skadelik is, word min verstaan. Die huidige aanvoorstudie dui aan watter dele van die lokomotoriese patroon gedetailleerde verdere studie verdien. Basies word daar by die dra van 'n koplas korter, vinniger, "trippel"stappies geneem, wat die energievereistes van die stapbeweging verhoog. Die skokbreekmeganismes word beskadig. Aandryfmeganismes word gewysig.

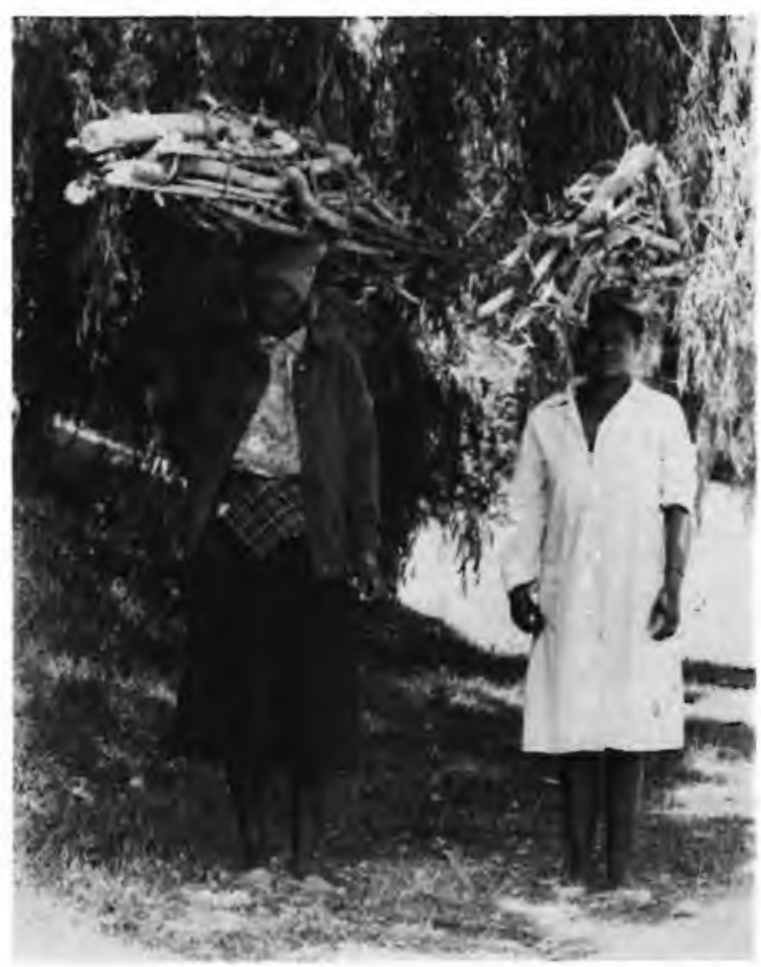

Fig. I. Headload carriers in the field. 
lengths and shorter stride times, indicating that smaller steps were being taken at a higher frequency, i.e. "mincing".

Presented here are some preliminary findings from our on-going study of normal versus head-loaded walking. Heavy load transporting by the head is a practice which intuitively one would expect may be medically hazardous, particularly considering the gracile nature of nuchal structures and the fact that loads must be supported in dynamic equilibrium and this over considerable distances and variable environmental conditions of gradient, surface irregularity and ambient temperature, to mention but a few. The chronic effects of occupational head-loading can at this time only be guessed at. Orthopaedic and physical medical health care across Africa is nowhere near parity with that enjoyed in affluent modern societies, which means that hazardous practices are poorly or not at all researched, let alone discouraged before the fact or treated after the fact.

There is no reason to believe that Africa will mechanise in the forseeable future to the extent that head carriage of heavy loads is likely to die out.

\section{MATERIALS AND METHODS}

We have described elsewhere techniques for measuring the temporal and distance kinematics of the patterns of foot-floor contact in normal and pathological gaits. ${ }^{3,4}$ Use of these and various other techniques for the measurement of kinematic parameters in human locomotion have resulted in a rich literature on the subject of temporal-distance and angular kinematics, of which Charteris and Taves, ${ }^{5}$ Rosenrot, Wall and Charteris ${ }^{5}$ and Wall and Charteris; 7,8 are a few examples.

In this preliminary analysis four Black female occupational woodcarriers each underwent two conditions:

a) normal (unloaded) walking

b) head-loaded walking carring a load of fire-wood $40 \%$ of body mass and $160 \%$ of stature.



Fig. 2. Subject in the laboratory at start of a loaded-condition traverse.
Each subject traversed a walkway of $20 \mathrm{~m}$ several times, at walkıng speeds spanning the normal human range from slow to fast. These traverses were done without carrying any objects and barefooted. A total of 10 traverses by each subject established a profile of normal walking through the range of speeds. Each subject then repeated the procedure carrying the headload. The technology used consisted of a foot-switch telemetry system (B and L Engineering)* designed 10 differentiate contact periods at the heel, fore-foot (metatarsals 5 and 1) and big toe, and combinations of these. A small transmitting system, worn on a waist belt, sent signals to a recelving/decoding unit, creating input from both feet as voltage charges on two channels of a biological recorder (Physiograph). The recorder (paper speed $5 \mathrm{~cm} \mathrm{~s}^{-1}$ ) produced foot-contact traces which were analysed over a $6 \mathrm{~m}$ distance of the walkway bounded by photo-cells set up to determine the average walking velocity in this central portion of the walkway. Temporal pulses from each foot-switch were measured manually and the data input into an Apple IJe microprocessor to assist in data-reduction and statistical analysis.

Throughout this speed-related study we have expressed walking speed in units, not of $\mathrm{m.s}^{-1}$, but in statures $s^{\prime}$, which allows comparisons using subjects ol different body-length.

\section{RESULTS}

\section{A. The Overall Pattern}

The head-load pattern viewed as a whole, is one of minced steps, shown as shorter stride times, higher step frequencies and shorter step lengths. These various ways of saying the same thing viz that headloaders mince, or clip, their steps, are depicted in graphs (A) (B) and (C) of Figure 3.

In human walking, contact time is always longer than swing phase, but as speed increases so the percentage of stride time devoted to contact decreases, while that devoted to swing increases and the swing-to-support ratio consequently grows larger. These relationships are shown in Figure 4. In fact, under headloading all the above patterns are maintained, though at very different levels, a notable exception being graph (D) of Figure 3: raw contact time is unaffected by headloading.

Because the raw contacts are the same but the headloaded stride time always shorter, it follows that under the headload condition contact is relatively longer as a percentage of stride time, as implied in Figure 3 (D). So the minced stepping pattern under headload is one in which the recovery (swing) is not only shorter with the shorter step, but faster relative to the stride cycle. The reduced swing-to-support ratio under headload shows the basic overall pattern difference: in headload walking the aim is to reduce the less stable single support (c.f. swing) phase, both absolutely and rela-

\footnotetext{
*B and L Engineering, 9618 Sante Fe Springs Ro.. Sante Fe Springs, California 90670 , USA.
} 



Fig. 3. Temporal, distance and rate parameters of the overall pattern. Broken line represents unloaded condition; solid line represents loaded condition.

tively, and to increase the stable portion of the cycle. By inference, if single support (hence swing) is shorter, but overall contact (Fig. 3(D)) is absolutely the same and relatively longer, it must mean that the periods of double support, necessarily the most stable, are absolutely and relatively longer.
Separate measurement of raw double support times reveals that these are always longer in the headload condition (Figure 5). Given that overall contact times are identical between conditions, it follows that, relative to total contact, double support is a bigger percentage value headloaded, than normal. 
(A)



(B)



(C)



Fig. 4. Support-time, swing time relationship. Broken line represents unloaded condition; solid line represents loaded condition.

\section{B. Breakdown of Foot-Floor Contact Components}

Breakdown of the sequence of foot-to-floor contacts reveals how the mincing pattern is composed: we expect that at faster speeds the shock-absorbing phase from heel-strike to foot-flat (which we call the braking mechanism) will reduce in normal circumstances. However, under heavy headloading, the same small pretibial muscles, now working as shock absorbers against a load considerably closer to their maximal capacity, are less effective in cushioning the impact of heel-strike. Thus, in an absolute and relative sense with respect to total contact time, the braking mechanism is less effective under headloading; the foot-slap is earlier and sharper. One positive effect of this is that a greater surface area (that of the whole foot), is earlier posed to the walking surface, increasing stability and dissipating pressures (Figure 5B).

The foot-flat phase, in which heel and at least ball are in contact with the substrate, is always relatively longer as a percentage of contact in the headload condition (Figure 5C). This is especially significant since the heel disengages from the walking surface relatively earlier in the headload condition.

This implies that greater propulsive effort is required to move walker plus head-load carried, and that plantar thrust from the calf muscles causes an earlier than normal rise of the heel. It must be pointed out that heel-rise does not itself mean that calf propulsion is the cause; for the heel may disengage passively without muscle activity from the calf group. However, the step is shorter under headload, so that the centre of mass is not far forward of the rear leg at this time, which would argue against a passive heel-rise: it is more likely that the heel rises absolutely and relatively earlier under headloading because of a greater strain on the calf group.

\section{DISCUSSION}

Headload walking is a pattern in which the dictates of load-balance and load mass combine to produce a longer double-support phase, a relatively longer contact phase, a short, quick swing and a smaller, faster, more mincing pace at the same overground velocities of walking. Under headloading, the foot slaps down earlier, implying less effective cushioning of the heel-strike, and the heel rises earlier from the ground than under normak conditions. The period of foot-flat between the braking and the propulsive phases at each end of the contact period, is longer under headloading. All these phenomena help to explain how balance is maintained and heavy loads are sustained by headload carriers.

The adaptations of headload carriers are complex and involve significant differences from normal walking; but these are always differences of degree, not of kind; patterns are accentuated or attenuated, but not reversed or obliterated. This overall finding prompts an observation in reverse from emphasis on the differences between normal and headload walking: given the nature of the loads carried in this study, comprising woodbundles $160 \%$ of stature in length and $40 \%$ of body mass in load, it is remarkable how natural the elicited gait pattern is; how stable the normal pattern of human locomotion is to be so little disrupted. 



Fig. 5. Breakdown of foot-floor contact components. Broken line represents unloaded condition; solid line represents loaded condition. 


\section{CONCLUSION}

The significant contribution of this preliminary analysis is that it strongly suggests that the most productive areas for detailed research in future should concentrate on the causes of reduced shock-absorption (from heel-strike to foot-flat) and on the question of whether heel-rise is caused by passive 'over-ride' of the rear limb or active muscular propulsion by the gastrocnemius-soleus complex, or is just an artefact of the fast stepping frequency.

Angular kinematic analysis, concentrating on the knee and the hip, should assist in obtaining answers to the above questions, as well as in suggesting what the effects might be on these joints of the habitual practice of head-load walking. These are the subjects of our ongoing analysis.

\section{References}

1. Datta SR and Ramanathan NL. Ergonomic comparison of seven modes of carrying loads on the horizontal plane. Ergonomics 1971; 14(2): 269-278.

2. Eke-Okoro ST and Sandlund B. The effects of load, shoes, sex and direction on the gait characteristics of street pedestrians. Journal of Human Movement Studies 1984; 10: $107-114$.
3. Wall JC, Charteris $\mathbf{J}$ and Hoare JW. An automated online system for measuring the temporal patterns of foot/ floor contact. $J$ Med Eng Technol 1978; 2(4): 187-190.

4. Wall JC, Charteris J and Hoare JW. An automated system for the analysis of gait. Proceedings: XII International Conference on Medical and Biological Engineering and $V$ International Conference on Medical Physics Aug 19-24 1979; Jerusalem, lsrael.

5. Charteris $\mathbf{J}$ and Taves $\mathbf{C}$. The process of habituation to treadmill walking: a kinematic analysis. Percept Mot Skills 1978; 47: 659-666.

6. Rosenrot P, Wall JC and Charteris $J$. The relationship between velocity, stride time, support time and swing time during normal walking. Journal of Human Movement Studies 1980; 6: 323-335.

7. Wall JC and Charteris J. The process of habituation to treadmill walking at different velocities. Ergonomics 1980; 23(5): 425-435.

8. Wall JC and Charteris J. A kinematic study of long-term habituation to treadmill walking. Ergonomics 1981; 24(7): 531-542.

\section{Bibliography}

Charteris J. Human gait cyclograms: conventions, speed relationships and clinical applications. Int J Rehabil Res 1982; 5(4): $507-518$.

\section{NEWS OF COURSES \& CONGRESSES}

WCPT IOTH INTERNATIONAL CONGRESS: AUSTRALIA MAY 1987

\section{Pre-Congress Courses}

11-15 Spinal Manipulative Therapy

11-12 Action, Movement and Motor Processes

13-15 Health Education in the Workplace Topics and Techniques

14-16 Motor Training Following Stroke

\section{Post-Congress Courses}

24-28 Introduction to Manual Therapy

24-27 Women's Health: Managing Life's Stages and Transitions - The Physicial Therapist's Contribution

$24 \quad$ Clinical Reasoning and Clinical Decision Making

25-27 Health Management for the Aged - lssues and Initiatives

25-27 Assessment of Motor Development and Follow up of the Preterm and At Risk Infant

25-27 The Management of Sporting Injuries:

Directions from Research

29 Exercise and Rehabilitation

For further information write to:

Pre and Post Congress Courses

Australian Physiotherapy Association

P.O. Box 119, Concord

Australia 2137.

\section{DEPARTMENT OF HEALTH AND WELFARE COURSE IN HUMAN GENETICS I2-23 MAY 1986}

Venue: Opera Plaza Building, Pretoria.

Content: The basic principles of Human Genetics and the practical application thereof in the provision of a comprehensive health service.

Expenses: The course is free. Participants are responsible for their own accommodation and travel expenses.

Applications: Closing date 7 March 1986.

Please apply to Mrs. E. van der Merwe, Department of Health and Welfare, Private Bag X63, Pretoria 0001.

Please note: (1) All applications are subject to selection.

(2) A pre-requisite for the course is a basic knowledge of cell physiology, including mitosis and meiosis.

CONGRESS HALLIWICK IN 1986

THE REALITIES OF MOVEMENT IN WATER

Date: $\quad$ 13-15 August 1986.

Venue: University of Nijmegen, Netherlands.

Language: English.

Number of participants: \pm 400

Details from: Halliwick in ' $86, \mathrm{c} / \mathrm{o}$ Mrs. L. van Herk, P.O. Box 9101, 6500 HB Nijmegen, Netherlands. 